\title{
Correlation between Emotional Intelligence and Nurse Work Stress in Hospitalization Services, Undata Hospital
}

\author{
Muhammad Ryman Napirah*(iD, Vidyanto Untad (D), Siti Alfani \\ Department of Health Administration and Policy, Faculty of Public Health, Tadulako University, Palu, Indonesia
}

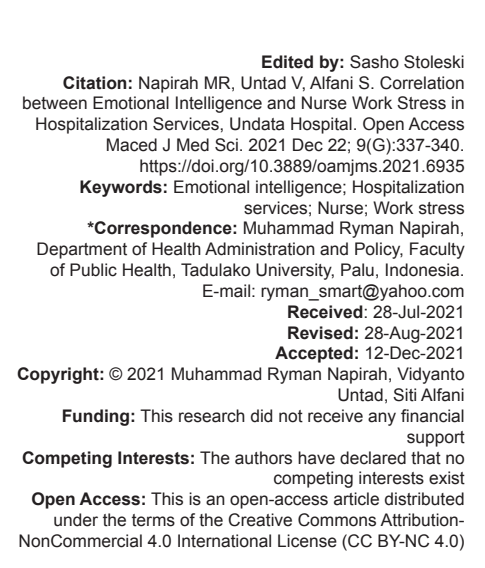

\begin{abstract}
BACKGROUND: The high work demands on nurses in their work, the greater the possibility of a nurse experiencing work stress.

AIM: This study aimed to determine the relationship between self-awareness, self-regulation, self-motivation, empathy, and social skills with the work stress among nurses in the hospitalization services of Undata Hospital, Central Sulawesi Province.

METHOD: It was a quantitative research with a cross-sectional approach and using the accidental sampling method. Data were collected by a questionnaire with a Likert scale and the WHO DASS questionnaire toward 63 respondents and statistically analyzed using the Chi-square test.

RESULTS: A relationship between self-awareness $(p=0.034)$, self-management $(p=0.044)$, self-motivation $(p=0.012)$, empathy $(p=0.021)$, and social skills $(p=0.026)$ with work stress among nurses in hospitalization services of Undata Hospital, Central Sulawesi Province.

CONCLUSION: Emotional intelligence affects the nurses' work stress in a hospital during work implementation.
\end{abstract}

\section{Introduction}

Emotional intelligence is the ability to manage emotions related to other people. This emotional intelligence includes self-knowledge, self-control, motivating, empathizing, and fostering social relationships [1]. One of the factors that influence stress is emotional intelligence. According to the Goleman (2007) [2], emotional intelligence can determine a person's success. Emotional intelligence is an ability to motivate oneself to survive bad mood disorders so that the burden of stress does not hinder the mind in doing a job. Research from the National Institute for Occupational Safety and Health defines nurses as professionals with a very high-risk of stress. Selye (1975) [3] found that the reason why the nursing profession has a high-risk of exposure to stress $(98 \%)$ is that nurses have duties and very high responsibility for the safety of human life [4], [5]. In Shebin El Kom University Hospital in Egypt, the average emotional intelligence of nurses is at a low level [6]. The centers for disease control study results also show that an average of 19 people dies each week in the United States due to stress-related to emotional problems with coworkers and customers [7].
According to a survey from the Indonesian Nurses Association (in Indonesian: Persatuan Persatuan Perawat Indonesia, abbreviated as PPNI) in 2006 , about $50.9 \%$ of nurses working in four provinces in Indonesia experience work stress. The workers often feel dizzy, tired, and have insomnia because the workload is too high and time-consuming and also they have low salaries without adequate intensive care. The PPNI, as an organization of nurse associations in Indonesia, has drafted an appropriate law to regulate the rights of nurses to reduce the stress problems experienced among nurses [7].

There are 4530 nurses in the Central Sulawesi, with a percentage of the performance of providing care that is not following the provision of services, about $74 \%$, compared to the suitability of providing services to patients of $21 \%$ [8]. The Undata, A Palu Regional General Hospital (In Indonesian: Rumah Sakit Umum Daerah, abbreviated as RSUD), is one of the most referral hospitals in the Central Sulawesi [9].

This study aimed to analyze the relationship between emotional intelligence and work stress among nurses in the hospitalization services of Undata Hospital, Central Sulawesi Province. 


\section{Methods}

The type of research used was an analytic survey with a cross-sectional study design. The research was conducted at Undata Hospital. Research respondents are nurses who work at Undata Hospital, namely, 63 people using the slovin formula.

The data collected are emotional intelligence, namely, self-awareness, self-regulation, self-motivation, empathy, and social skills using a questionnaire and the type of questionnaire scale, namely, the Likert scale which is divided into four options, namely, strongly disagree, disagree, agree, and strongly agree. The emotional intelligence questionnaire used by nurses has been tested for validity and reliability which show that the questionnaire is valid and reliable. The work stress questionnaire for nurses uses the WHO DASS Questionnaire [10] with 42 questions with four answer options, namely, zero (none or never), one (according to what is experienced to a certain degree, sometimes), two (often), and three (very well experienced, or almost every time). Stress category if the score is 25 and not stressed if the score is $<25$.

Analysis of the data used is the Chi-square test with a significance level of $p<0.05$ and using the Statistical Package for the Social Sciences program.

\section{Results and Discussion}

According to the characteristics of respondents based on univariate analysis, the age group of $26-30$ years was 22 respondents $(34.9 \%)$. Females were dominated based on gender, about 22 respondents $(34.9 \%)$, while males were two respondents $(3.2 \%)$. Most respondents had an associate degree (in Indonesian: Diploma III) as many as 22 respondents (34.9\%). Furthermore, 22 respondents $(34.9 \%)$ were civil servants and 22 respondents $(34.9 \%)$ had the longest working period.

\section{Correlations between emotional intelligence and work stress among nurses of Undata Hospital}

\section{Self-awareness}

Based on the Chi-square test on self-awareness with nurses' work stress was found $p=0.034(\alpha<0.05)$, there was a relationship between self-awareness and work stress of nurses in the hospitalization services at Undata Hospital, Central Sulawesi Province (Table 1). Nurses at Undata Hospital generally had the high emotional intelligence to realize and understand the whole process within themselves, feelings, thoughts,
Table 1: The correlation between the independent variable and the dependent variable

\begin{tabular}{|c|c|c|c|c|c|c|c|}
\hline \multirow[t]{3}{*}{ Variables } & \multicolumn{4}{|c|}{ Nurse work stress } & \multirow{2}{*}{\multicolumn{2}{|c|}{ Total }} & \multirow[t]{3}{*}{ p-value } \\
\hline & \multicolumn{2}{|c|}{ Work stress } & \multicolumn{2}{|c|}{ Non-work stress } & & & \\
\hline & $n$ & $\%$ & $\mathrm{n}$ & $\%$ & $\mathrm{n}$ & $\%$ & \\
\hline \multicolumn{8}{|c|}{ Self-awareness } \\
\hline Poor & 23 & 69.7 & 10 & 30.3 & 33 & 100 & \multirow[t]{3}{*}{0.034} \\
\hline Good & 12 & 40.0 & 18 & 60.0 & 30 & 100 & \\
\hline Total & 35 & 55.6 & 28 & 44.4 & 63 & 100 & \\
\hline \multicolumn{8}{|c|}{ Self-regulation } \\
\hline Poor & 20 & 71.4 & 8 & 28.6 & 28 & 100 & \multirow[t]{3}{*}{0.044} \\
\hline Good & 15 & 42.9 & 20 & 57.1 & 35 & 15 & \\
\hline Total & 35 & 55.6 & 28 & 44.4 & 63 & 35 & \\
\hline \multicolumn{8}{|c|}{ Self-motivation } \\
\hline Poor & 21 & 70.0 & 9 & 30.0 & 30 & 100 & \multirow[t]{3}{*}{0.012} \\
\hline Good & 14 & 42.4 & 19 & 57.6 & 33 & 100 & \\
\hline Total & 35 & 55.6 & 28 & 44.4 & 63 & 100 & \\
\hline \multicolumn{8}{|l|}{ Empathy } \\
\hline Poor & 20 & 74.1 & 7 & 25.9 & 27 & 100 & \multirow[t]{3}{*}{0.021} \\
\hline Good & 15 & 41.7 & 21 & 58.3 & 36 & 100 & \\
\hline Total & 35 & 55.6 & 28 & 44.4 & 63 & 100 & \\
\hline \multicolumn{8}{|c|}{ Social Skills } \\
\hline Poor & 21 & 72.4 & 8 & 27.6 & 29 & 100 & \multirow[t]{3}{*}{0.026} \\
\hline Good & 14 & 41.2 & 20 & 58.8 & 34 & 100 & \\
\hline Total & 35 & 55.6 & 28 & 44.4 & 63 & 100 & \\
\hline
\end{tabular}

and the background of their actions. Nurses can connect with their emotions and thoughts, besides realizing every emotion that arises every work time, to minimize work stress on them. This study is in line with research conducted by Rakhshani T (2018) [11], showing an association between self-awareness and work stress of nurses at Shiraz Hospital, Iran. The correlation test shows a relationship between self-awareness of work stress with Chi-square test results $p<0.001$.

According to the Satrianegara (2017) [12], the research shows that the self-awareness assessment criteria have a good relationship with the organizational behavior of nurses at the Faisal Islamic Hospital in Makassar in 2015, and the results of statistical tests obtained $p=0.000$.

\section{Self-regulation}

Based on the analysis results using the Chisquare test, which was carried out on self-regulation with nurses' work stress, $p=0.044(\alpha=0.05)$ was found. Then, there was a relationship between self-regulation and work stress of nurses in the hospitalization services, Undata Hospital, Central Sulawesi Province (Table 1). These results indicated that nurses' self-regulation correlated with nurses' work stress. It showed by the nurses not having good self-regulation, not thinking calmly, and being impatient when dealing with other people. They quickly bored at work to patients who often ask for help, unable to regulate their emotions even during these situations.

Thus, the self-regulation component is needed by a nurse. According to the Sastrawinata (2011) [13], self-regulation is to handle emotions so that it has a positive impact on the implementation of tasks, is sensitive to conscience, can delay enjoyment before achieving a goal, and can recover from emotional stress. This study is in line Tagoe (2017) [14], a significant relationship between self-regulation and works stress for nurses in Accra, Ghana, Africa by Chi-square test 
results of $p<0.000$. Research by Yamani (2014) [15] shows a significant relationship between self-regulation variables and work stress of $p=0.020$ in students of the Faculty of Medical Sciences, Isfahan University, Iran.

The research of Afnuhazi (2019) [4] that there were 48 people $(68.6 \%)$ of nurses whose emotional intelligence is not experiencing work stress or normal showed a significant relationship between the emotional intelligence of nurses and the level of work stress of nurses at Achmad Mochtar Hospital, Bukittinggi.

\section{Self-motivation}

Based on the results of the Chi-square test on self-motivation with nurses' work stress, it was found that the value of $p=0.012(\alpha=0.05)$ then there was a relationship between self-motivation and work stress of nurses in the hospitalization services at Undata Hospital, Central Sulawesi Province (Table 1). These results indicated that self-motivation had a relationship with work stress among nurses. Nurses who are always motivated to improve or meet high standards also play a role in various information and new ideas in the workplace [16], [17], [18]. They will avoid stress in the work environment and vice versa if nurses who have many burdens on their minds will be lazy to work and determine work motivation.

This research is also in line with the theory put forward by Goleman (2015) [19] that a person who has high self-motivation will be able to set high standards, acting as a model of action. Research by Tagoe (2017) [14] found a significant relationship between self-motivation and work stress for nurses in Accra, Ghana, and Africa. Correlation test with Chi-square test results of $p<0.000$. Another research finding, Opuni (2015) [20], shows that self-motivation is positively related to service quality $(r=0.889$ and $p=0.000)$ and customer satisfaction $(r=0.573$ and $p=0.000)$ in the stelecommunications sector in Ghana. This study is also in line with Napirah (2012) [21], a relationship between the head of the room's self-motivation and nurses' work motivation in the Inpatient Installation of the Southeast Sulawesi Provincial Hospital $(p=0.021)$. This is due to a strong drive to achieve something, always optimistic even in the face of failure, and the high organizational commitment shown by the head of the room resulted in increased work motivation of nurses.

\section{Empathy}

Based on the analysis using the Chi-square test on nurses' empathy and work stress, $p=0.021$ $(p<0.05)$ was considered. There was a relationship between empathy and work stress of nurses in the outpatient care hospitalization at Undata Hospital, Central Sulawesi Province (Table 1). These results indicated that nurses' empathy is related to nurses' work stress. It is marked that people who can perform social skills or social relations are emotionally intelligent. They can establish relationships with other people and enjoy friendships. Sincerity requires selfawareness and emotional expression so that when talking to someone, we can express feelings openly, including any disturbances that hinder a person's ability to express feelings openly.

Tagoe (2017) [14] reveals a significant relationship between empathy and work stress for nurses in Accra, Ghana, and Africa, with Chi-square test results $p<0.000$. Al-Faouri (2014) [22] also showed a significant positive relationship between empathy and the level of job satisfaction $(r=0.653$ and $p=0.000)$ in Jordanian Hospitals. This study is also in line with research conducted by Rakhshani (2018) [11], an association between empathy for nurses' work stress at Shiraz Hospital, Iran, with a Chi-square test results $p<0.001$.

\section{Social skill}

According to the Chi-square test, which was carried out on social skill with nurses' work stress, $p=0.026(p=0.05)$ was considered. Then, there was a relationship between self-awareness and the work stress of nurses in the hospitalization services of Undata Hospital, Central Sulawesi Province (Table 1). Thus, a nurse's social skills component is needed, as the theory Goleman (2015) [19] that people who can perform social skills or social relations are emotionally intelligent. Emotionally, intelligent people will be able to establish relationships with other people, they can enjoy sincere friendships. Sincerity requires selfawareness and emotional expression. When talking to someone, we can express feelings openly, including any disturbances that hinder a person's ability to express feelings openly.

\section{Conclusion}

This research conducted at the Undata Hospital, Central Sulawesi Province, indicated the correlation between self-awareness, self-regulation, self-motivation, empathy, and social skills toward work stress among the nurses there.

\section{References}

1. Saleh A, Ramly M, Gani MU, Suriyanti S. Factors affecting the job satisfaction and performance of nurses private hospitals Class B in Makassar. Int J Sci Technol Res. 2016;5(10):74-83.

2. Goleman D. Emotional Intelligence: Kecerdasan Emosional 
Mengapa El Lebih Penting Daripada IQ. Jakarta: Gramedia Pustaka Utama; 2007.

3. Selye H. Stress without Distress. New York: Signet Books; 1975.

4. Afnuhazi R. The relationship between emotional intelligence and work stress of nurses in the Ambun Suri Hospital Dr. Achmad Mochtar Bukittinggi. J Akademika Baiturrahim Jambi. 2019;8(1):126-34.

5. Berland A, Natvig GK, Gundersen D. Patient safety and jobrelated stress: A focus group study. Intensive Crit Care Nurs. 2008;24(2):90-7. https://doi.org/10.1016/j.iccn.2007.11.001 PMid: 18096388

6. Bakr MM, Safaan SM. Motional intelligence: A key for nurses performance. J Am Sci. 2012;8(11):385-93.

7. Muhsinin SZ, Suryani S. Hubungan Kecerdasan Emosional dengan Tingkat Stres Kerja Perawat di Ruang Rawat Inap RS PKU Muhammadiyah Yogyakarta. Yogyakarta: Universitas Aisyiyah Yogyakarta; 2009. Available from: https://www.lib. unisayogya.ac.id [Last accessed on 2021 Jul 23].

8. Kementerian Kesehatan RI. Infodatin: Situasi Tenaga Keperawatan. Jakarta: Kementerian Kesehatan RI; 2017.

9. Dinkes Sulteng. Profil Kesehatan Provinsi Sulawesi Tengah Tahun 2017. Palu: Dinas Kesehatan Sulawesi Tengah; 2018.

10. Crawford JR, Henry JD. The depression anxiety stress scales (DASS): Normative data and latent structure in a large nonclinical sample. Br J Clin Psychol. 2003;42(2):111-31. https:// doi.org/10.1348/014466503321903544

PMid:12828802

11. Rakhshani T, Motlagh Z, Beigi V, Rahimkhanli M, Rashki M. The relationship between emotional intelligence and job stress among nurses in Shiraz, Iran. Malays J Med Sci. 2018;25(6):100-9. https://doi.org/10.21315/mjms2018.25.6.10 PMid:30914883

12. Satrianegara MF, Aeni S, Rizal NI. Hubungan kecerdasan emosional terhadap perilaku organisasi perawat di rawat inap rumah sakit islam faisal kota makassar tahun 201. Al-Sihah Public Health Sci J. 2017;9(1):55-62. Available from: http://www. journal.uin-alauddin.ac.id/index.php/al-sihah/article/view/3147 [Last accessed on $2021 \mathrm{Jul} 23$ ]
13. Sastrawinata H. Pengaruh kesadaran diri, pengaturan diri, motivasi, empati, dan keterampilan sosial terhadap kinerja auditor pada kap di kota palembang. SOSIALITA. 2011;1(2):1-19. Available from: http://www.jurnal.ubl.ac.id/index.php/JIA/article/ view/359 [Last accessed on $2021 \mathrm{Jul} 23$ ]

14. Tagoe T, Quarshie EN. The relationship between emotional intelligence and job satisfaction among nurses in Accra. Nurs Open. 2017;4(2):84-9. https://doi.org/10.1002/nop2.70 PMid:28286664

15. Yamani N, Shahabi M, Haghani F. The relationship between emotional intelligence and job stress in the faculty of medicine in Isfahan University of Medical Sciences. J Adv Med Educ Prof. 2014;2(1):20-6. PMid:25512914

16. Hayati $D$, Charkhabi $M$, Naami $A$. The relationship between transformational leadership and work engagement in governmental hospitals nurses: A survey study. Springerplus. 2014;3(1):25. https://doi.org/10.1186/2193-1801-3-25 PMid:24455469

17. Ten Hoeve $Y$, Jansen G, Roodbol P. The nursing profession: Public image, self-concept and professional identity. A discussion paper. J Adv Nurs. 2014;70(2):295-309. https://doi. org/10.1111/jan.12177 PMid:23711235

18. Taylor BM. The integrated dynamics of motivation and performance in the workplace. Perform Improv. 2015;54(5):28-37.

19. Goleman D. Emotional Intelegence-Kecerdasan Emosional. Jakarta: Gramedia Pustaka Utama; 2015.

20. Opuni F. An Analysis of the Impact of Emotional Intelligence on Service Quality and Customer Satisfaction in the Telecommunication Sector in Ghana. IJSMMRD. 2015;5(1):37-52.

21. Napirah RM. Hubungan Kecerdasan Emosional Kepala Ruangan Degan Motivasi Kerja Perawat Di Rsud Sulawesi Tenggara. Makassar: Universitas Hasanudin; 2012.

22. Al-Faouri I, Al Ali N, Al Shorman B. The influence of emotional intelligence training on nurses' job satisfaction among Jordanian nurses. Eur J Sci Res. 2014;117(4):486-94. 